\title{
Correlation Individual Characteristics and Work Stress with Menstrual Disorders in Tobacco Farmers
}

\author{
Hubungan Karakteristik Individu dan Stres Kerja dengan Gangguan Menstruasi \\ pada Petani Tembakau
}

\author{
Indriyanti, Tri Martiana, Firman Suryadi Rahman \\ Department of Occupational Safety and Health, Faculty of Public Health Universitas Airlangga \\ Campus C Mulyorejo, Surabaya, East Java 60115, Indonesia
}

\begin{abstract}
Introduction: Women participation at work, especially in the agricultural sector, implies a status of gender equality thatwomen are capable of doing work like men. However, women naturally have physically and biologically differenced with men, for example in reproductive health conditions. Menstrual disorders are important to know because it can show the function of women reproductive health disorder. Menstrual disorders can be caused by various factors. The purpose of this study was to identify individual characteristics and psychological factor (work stress) with menstrual disorders of female tobacco farmers in Ambulu Village, Jember City. Methods: This study was an observational analytic with a cross-sectional approach. The research was conducted on August 2018 and the respondents were 36 female tobacco farmers chosen by simple random sampling. Dependent variable of this study was menstrual disorders and the independent variables were individual characteristics (age, marital status, and work period) and psychological factor (work stress). Results: Obtained were that most of the respondents aged 35-44 years (55.6\%), married (91.7\%), having work period over 5 years (69.4\%) and 58.3\% respondents experienced a moderate level of work stress. Conclusion: There was a relationship between work stress and menstrual disorders. There was no relationship between individual characteristics with menstrual disorders in tobacco farmers in Ambulu Village, Jember City.
\end{abstract}

Keywords: individual characteristics, menstrual disorders, work stress

\section{ABSTRAK}

Pendahuluan: Keikutsertaan wanita pada sektor pekerjaan, khususnya di sektor pertanian menyiratkan status kesetaraan gender yang menempatkan perempuan mampu melakukan pekerjaan seperti pria. Namun, wanita secara alami berbeda secara fisik dan biologis dengan pria, misalnya pada kondisi kesehatan reproduksi. Gangguan mentruasi sangat penting untuk diketahui karena dapat menjadi indikator adanya gangguan pada sistem kesehatan reproduksi wanita. Terjadinya gangguan menstruasi dapat disebabkan karena berbagai faktor. Tujuan dari penelitian ini adalah untuk menganalisis hubungan karakteristik individu dan stress kerja dengan gangguan menstruasi pada petani tembakau di Desa Ambulu, Kecamatan Ambulu, Jember. Metode: Penelitian ini adalah penelitian observasional analitik dengan desain penelitian cross sectional. Penelitian ini dilakukan pada bulan Agustus 2018 dan sampel pada penelitian ini sebanyak 36 responden petani tembakau di Desa Ambulu dan dipilih dengan menggunakan simple random sampling. Variabel dependen pada penelitian ini gangguan menstruasi, dan variable independennya adalah karakteristik individu (usia, status pernikahan, dan masa kerja) dan faktor psikologi yaitu stres kerja. Hasil: Penelitian adalah sebagian besar responden berusia 35-44 tahun (55,6\%), berstatus telah menikah (91,7\%), masa kerja $>5$ tahun (69,4\%), dan termasuk stres kerja sedang (58,3\%). Simpulan: Penelitian adalah terdapat hubungan antara stress kerja dengan gangguan menstruasi, tetapi tidak terdapat hubungan antara karakteristik individu dengan gangguan menstruasi pada petani tembakau di desa Ambulu, Kabupaten Jember.

Kata kunci: gangguan menstruasi, karakteristik individu, stres kerja

\author{
Author for Correspondence: \\ Indriyanti \\ Email: idr.yanti@yahoo.com \\ Telephone: +6285249475049
}

(C2019 IJOSH All right reserved. Open access under CC BY NC-SA license doi: 10.20473/ijosh.v8i3.2019.249-257 Received January 11, 2019, received in revised form February 20, 2019, Accepted November 04, 2019, Published: December 2019 


\section{INTRODUCTION}

Women who are involved in various sectors of the work world are increasing. Based on data released by Statistics Indonesia, the number of female workers has increased every year. The presentation of the number of female workers reached $50 \%$ higher than the number of male workers. In the National Labor Force Survey conducted by Statistics Indonesia in 2016, the number of women working was around 45.5 million, and one sector that employed a lot of female labor was the agricultural sector (Direktur Statistik Kependudukan dan Ketenagakerjaan, 2017).

The agricultural sector is one of the strategic sectors which is second highest contribution $(14.4 \%)$ after the manufacturing industry sector $(23.7 \%)$. The agricultural sector is a leading section because it plays an important role in the economy of the countryside. The agricultural sector supports the development of the industrial sector both upstream and downstream, as a producer of foreign exchange. In addition, the agricultural sector is also in accordance with the nature of this nation as an agricultural and maritime country. Besides, the agricultural sector is also able to absorb labor in rural areas around 40\% (Biro Riset BUMN, 2015).

Women's participation in the world of work such as in the agricultural sector implies a status of gender equality that positions women as being capable of doing work like men. Therefore, female workers also have the right to improve social, economic, or other security. Nevertheless, women have differences with men and women, as is the case with women workers, such as in financial conditions, childbirth, postpartum period, and during other health care.

According to Ministry of Health Data and Information Center (2015) reproductive health is a comprehensive health condition, physical, mental and social aspects, not just the absence of disease or interference with everything related to the reproductive system, its function and the reproductive process itself. In general, reproductive health problems of women can include menstrual disorders, infertility, infectious disease infections, menopause, and others (Prawirohardjo, 2011).

Harlow, Windham and Paramsothy (2013) stated that menstruation is a periodic hemorrhage experienced by women in their reproductive cycle that starts from menarche. In term of normal menstruation, it is very important to know fertility, conception, or infertility disorders in women. According to Prawirohardjo (2011), in the menstrual process, there can be several disorders, one of them is called menstrual disorder such as amenorrhea, dysmenorrhea, polymenorrhea, oligomenorrhea, hypermenorrhea, hypomenorrhea, and metrorrhagia.

Menstrual disorders are complaints that often cause women to go to the doctor or first aid center. Complaints in menstrual disorders are vary from mild to severe and often cause frustration for the sufferer. Data in several industrialized countries states that a quarter of the population of women reported having had menorrhagia or hypermenorrhea, $21 \%$ complained that menstrual cycles shortened, $17 \%$ had metrorrhagia, and $6 \%$ complained of bleeding after intercourse. In addition to causing health problems, menstrual disorders also affect daily activities, as many as $28 \%$ reported being disturbed while working so this could have an impact on the economy (Prawirohardjo, 2011)

A cross-sectional study was also conducted on women of reproductive age in the United States. From this study, it is known that the number of women who experience dysmenorrhea ranges from $7 \%-15 \%$. This study states that dysmenorrhea accounts for $2.5 \%$ of the absence of female workers in factories and offices in the United States (Harlow, Windham and Paramsothy, 2013).

Hassani et al. (2014) stated that exposure to organic solvent in the workplace is known to be related to reproductive health problems, such as menstrual disorders, fertility, and able to affect pregnancy. Harsetianingrum (2015) showed the results of her research that the majority of female workers in a shoe factory in Sidoarjo experienced menstrual disorders. In this study, it was found that there was a relationship between the characteristic factors of individuals with menstrual disorders in female workers. Factors of individual characteristics studied were age, marital status, nutritional status, length of employment, length of work, and reproductive health history.

In the study of Mulastin (2011) the results of the majority of women in Polytron factory experienced stress and were known to experience normal menstrual cycles as many as 36 people $(58.1 \%)$, while the least number of workers experienced no stress was found to have an abnormal cycle of 26 people $(41.9 \%)$. From the statistical calculation in this study, it showed that there was a significant relationship between stress and the menstrual cycle in workers, with a p-value of 0.000 . 
Work stress can be caused by a variety of factors and is assessed from several measurements. In several studies on work stress that occur in women who work, it can lead to hypertension in pregnancy, preeclampsia, miscarriage, menstrual disorders, and dysmenorrhea. In addition, if it is accompanied by high work tension, it can cause premature birth (Lindbohm, Taskinen and Sallmén, 2013).

Zhou et al. (2010) showed that as many as $59.3 \%$ of female workers in China experienced work stress and are associated with menstrual disorders. Tarar et al. (2016) study also showed that female farmers in rural areas of Tehsil Dera, Ghazi Khan also experienced some of health problem relates to work. From the statistical test, it showed the majority $(90.6 \%)$ female farmers faced the health problem such as reproductive health problems, stress, injuries or sickness, asthma, and pesticide relates health problem.

Most of female farmers working tosupport their family so in socio economic problem and mental health (stress) (Tarar et al., 2016). Stress on female workers will cause axis activity in the hypothalamus, pituitary, and adrenals. Then, there will also be an increase in the levels of Corticotrophin Releasing Hormone (CRH) and Glucocorticoids. This causes the synthesis and metabolism of gonadotropin and estrogen to become surpressed, so that menstrual disorders can occur (Zhou et al., 2010).

Female workers have differences with male workers. It can be seen from their physical differences which include body size and strength, biological differences such as in the conditions of pregnancy, childbirth, menopause, menstruation, and others. There are also differences in socio-cultural where a woman has a dual role as a mother and resources in work (Suma'mur, 2009).

From the studies above, it is known that female workers in the formal sector such as industry or offices who experience menstrual disorders can cause performance to decline so that a decrease in work productivity can occur. This is because the more frequent reproductive health problems experienced by female workers, the level of absence from work will also be higher. Therefore, research needs to be done to see how menstrual disorders occur in nonformal sector workers such as agriculture.

Jember City is one of the agricultural and tobacco-producing areas with high-quality (Herminingsih and Rokhani, 2014). Based on data from Statistics Indonesia of East Java 2014, it is known that the area of tobacco farms in this city is increasing every year, wherein 2006-2013 there was an increase in the area of tobacco farming in Jember City. Each sub-district in Jember City consists of several villages, and there are several tobacco farmer groups in the village.

Based on Indonesian Center for Estate Crops Research and Development (2017) activities in farmer groups include planting that begins with soil extraction. Then the next stage is the maintenance of tobacco plants, which will be fertilized at the age of two months. The use of pesticides in tobacco farming can increase the risk of being exposed to irritants and chemicals, which is fertilizer. Other health risks in this work sector is the exposure of wet tobacco leaves that can increase the risk of Green Tobacco Sickness (GTS) (Sudibyo, 2015).

The best time to harvest tobacco is when the leaves are yellowish green. The work processes in the tobacco field such as planting, maintenance, pruning, and harvesting are sometimes carried out without any consideration of working hours. Working hours in this tobacco sector tend to be longer than 8 hours per day and the dominant work position is sit, especially in the harvesting seasons.

Work in the agricultural sector is not only done by male workers. Female workers also work in this sector, some are classified as temporary workers and some are unpaid family workers. Some tobacco farmers in Ambulu Village said that they had experienced menstrual disorders, such as long menstrual cycles, excessive fatigue when working during their period and some of them sometimes still work even in these conditions. If menstrual disorders happens continuously, it can be detrimental to female workers, which can reduce work performance and reduce worker productivity. Therefore, the purpose of this study was to analyze the relationship between individual characteristics and work stress with menstrual disorders in tobacco farmers in Ambulu Village, Jember City.

\section{METHODS}

This research was observational research type. Based on the problem and data analysis, this research includes the type of analytic research. In terms of time, this study is cross-sectional because it is to study the correlation between risk and effect factors by approaching, observing, and collecting data at the same time (Notoatmodjo, 2012). The population in this study were all female workers in tobacco farming in Ambulu village, Jember City with 39 workers. 
Sampling was done by simple random sampling and the sample was determined by the Lemeshow's formula so that the sample size was 36 workers. The research was conducted on August 2018. Variables in this study consisted of dependent variables which is menstrual disorders, and independent variables such as individual characteristics (age, marital status, and work period and psychological factors (work stress).

Primary data was obtained by interview using a questionnaire. The data of menstrual disorders in tobacco farmers was taken by using the Pictorial Blood Loss Assessment Chart (PBAC) questionnaire by Herman et al. (2017) and the Global Study of Women's Health Questionnaire. The assessment of work stress was taken by using a questionnaire from International Stress Management Association (ISMA) 2013. The data obtained was then analyzed in the form of tables and narratives consisting of univariate and bivariate analysis.

\section{RESULT}

The results were obtained using a questionnaire of individual characteristics (age, marital status, and work period) and psychological factors (work stress). Distribution of variables can be seen in the table and explanation below.

\section{Individual Characteristic}

Age

Based on Table 1, it can be seen that the majority of respondents of tobacco farmers at Ambulu Village, Jember City was between 35-44 years old which 20 people $(55.6 \%)$. It can also be seen that 25-34 years old category as many as 11 people $(30.6 \%),>44$ year as many as 3 people $(8.3 \%)$, and $15-24$ years as many as 2 people $(5.6 \%)$.

\section{Marital Status}

Based on Table 2, it can be seen that the majority of respondents of tobacco farmers at Ambulu Village, Jember City are married 33 people $(91.7 \%)$. The other categories are unmarried (5.6\%) 2 people and 1 respondent is divorce $(2.8 \%)$.

\section{Work Period}

Based on Table 3, it can be seen that the majority of respondents of tobacco farmers at Ambulu village, Jember City have a working period
Table 1. Distribution of Age on Tobacco Farmers at Ambulu Village, Jember City in 2018

\begin{tabular}{ccc}
\hline Age (years) & Frequency (n) & Percentage (\%) \\
\hline $15-24$ & 2 & 5.6 \\
$25-34$ & 11 & 30.6 \\
$35-44$ & 20 & 55.6 \\
$>44$ & 3 & 8.3 \\
\hline Total & 36 & 100.0 \\
\hline
\end{tabular}

Table 2. Distribution of Marital Status on Tobacco Farmers at Ambulu Village, Jember City in 2018

\begin{tabular}{ccc}
\hline Marital Status & Frequency (n) & Percentage (\%) \\
\hline Unmarried & 2 & 5.6 \\
Married & 33 & 91.7 \\
Divorce & 1 & 2.8 \\
\hline Total & 36 & 100.0 \\
\hline
\end{tabular}

Table 3. Distribution of Working Period of Tobacco Farmers at Ambulu Village, Jember City in 2018

\begin{tabular}{ccc}
\hline $\begin{array}{c}\text { Work Period } \\
\text { (years) }\end{array}$ & Frequency (n) & Percentage (\%) \\
\hline$\leq 5$ & 11 & 30.6 \\
$>5$ & 25 & 69.4 \\
\hline Total & 36 & 100.0 \\
\hline
\end{tabular}

Table 4. Distribution of Work Stress on Tobacco Farmers at Ambulu Village, Jember in 2018

\begin{tabular}{ccc}
\hline Work Stress & Frequency (n) & Percentage (\%) \\
\hline Low & 11 & 5.6 \\
Moderate & 21 & 91.7 \\
High & 4 & 2.8 \\
\hline Total & 36 & 100.0 \\
\hline
\end{tabular}

Table 5. Distribution of Menstrual Disorders on Tobacco Farmers at Ambulu Village, Jember City in 2018

\begin{tabular}{ccc}
\hline $\begin{array}{c}\text { Menstrual } \\
\text { Disorders }\end{array}$ & Frequency (n) & Percentage (\%) \\
\hline Yes & 24 & 66.7 \\
No & 12 & 33.3 \\
\hline Total & 36 & 100.0 \\
\hline
\end{tabular}


Table 6. Correlatin of Age with Menstrual Disorders on Tobacco Farmers at Ambulu Village, Jember City in 2018

\begin{tabular}{|c|c|c|c|c|c|c|c|}
\hline \multirow{3}{*}{ Age (Years) } & \multicolumn{4}{|c|}{ Menstrual Disorders } & \multirow{2}{*}{\multicolumn{2}{|c|}{ Total }} & \multirow{3}{*}{ p-value } \\
\hline & \multicolumn{2}{|c|}{ Yes } & \multicolumn{2}{|c|}{ No } & & & \\
\hline & n & $\%$ & n & $\%$ & $\mathbf{N}$ & $\%$ & \\
\hline $15-24$ & 1 & 50.0 & 1 & 50.0 & 2 & 100 & \multirow{4}{*}{0.601} \\
\hline $25-34$ & 7 & 63.6 & 4 & 36.4 & 11 & 100 & \\
\hline $35-44$ & 13 & 54.2 & 7 & 58.3 & 20 & 100 & \\
\hline$>44$ & 3 & 100 & 0 & 0 & 3 & 100 & \\
\hline Total & 24 & 66.7 & 12 & 33.3 & 36 & 100 & \\
\hline
\end{tabular}

Table 7. Correlatin of Marital Status with Menstrual Disorders on Tobacco Farmers at Ambulu Village, Jember City in 2018

\begin{tabular}{|c|c|c|c|c|c|c|c|}
\hline \multirow{3}{*}{ Marital Status } & \multicolumn{4}{|c|}{ Menstrual Disorder } & \multirow{2}{*}{\multicolumn{2}{|c|}{ Total }} & \multirow{3}{*}{ p-value } \\
\hline & \multicolumn{2}{|c|}{ Yes } & \multicolumn{2}{|c|}{ No } & & & \\
\hline & $\mathbf{n}$ & $\%$ & $\mathbf{n}$ & $\%$ & $\mathbf{N}$ & $\%$ & \\
\hline Unmarried & 1 & 50 & 1 & 50 & 2 & 100 & \\
\hline Married & 22 & 66.7 & 11 & 33.3 & 33 & 100 & 0.687 \\
\hline Divorce & 1 & 100.0 & 0 & 0.0 & 1 & 100 & \\
\hline Total & 24 & 66.7 & 22 & 33.3 & 36 & 100 & \\
\hline
\end{tabular}

of $>5$ years as many as 25 people $(69.4 \%)$. It can also be seen that 11 people $(30.6 \%)$ have a working period $\leq 5$ years.

\section{Work Stress}

Based on Table 4, it can be seen that the majority of respondents included moderate work stress category as many as 21 people $(58.3 \%)$. From the table above also can be seen that the category of low work stress as many as 11 people $(30.6 \%)$, and high work stress as many as 4 people $(11.1 \%)$.

\section{Menstrual Disorders}

Based on Table 5, it can be seen that the majority of respondents experienced menstrual disorders are 24 people (66.7\%), and those who did not experience menstrual disorders are 12 people $(33.3 \%)$. Menstrual disorders perceived by respondents are seen from the amount of bleeding, cycle or duration, and other disorders associated with menstruation.

\section{Correlation of Age with Menstrual Disorders}

From the Table 6, it is known that some respondents aged 35-44 years and experienced menstrual disorders as many as 13 people $(54.2 \%)$.
Based on the results of the statistical test, the value of Pearson Chi-Square is 1.820 with p-value of 0.610 . When it is compared to $\alpha$ of 0.05 , the $p$-value of 0.610 is greater than $\alpha$ so that it can be seen that there is no relationship between age and menstrual disorders in female farmers in Ambulu Village, Jember City.

\section{Correlation of Marital Status and Menstrual Disorders}

From Table 7, it is known that most of the respondents were married and had menstrual disorders as many as 22 people $(66.7 \%)$. Based on the results of statistical tests obtained the value of Pearson Chi-Square with p-value of 0.687 . When it is compared to $\alpha 0.05$, then the p-value of 0.687 is greater than $\alpha$ so that it can be seen that there is no relationship between marital status and menstrual disorder.

\section{Correlation of Work Period with Menstrual Disorder}

Most respondents have a working period $>5$ years and experience menstrual disorders are 16 people $(64 \%)$. Based on the results of statistical tests, the value of Fisher's Exact Test is obtained 
Table 8. Correlatin of Work Period with Menstrual Disorders on Tobacco Farmers at Ambulu Village, Jember City in 2018

\begin{tabular}{ccccccccc}
\hline \multirow{2}{*}{$\begin{array}{c}\text { Work Period } \\
\text { (years) }\end{array}$} & \multicolumn{9}{c}{ Menstrual Disorder } & & \multirow{2}{*}{ Total } & p-value \\
\cline { 2 - 6 } & $\mathbf{n}$ & $\mathbf{\%}$ & $\mathbf{n}$ & $\mathbf{\%}$ & $\mathbf{N}$ & $\mathbf{\%}$ & \\
\hline$\leq 5$ & 8 & 72.7 & 3 & 27.3 & 11 & 100 & \multirow{2}{*}{0.715} \\
$>5$ & 16 & 64.0 & 9 & 36.0 & 25 & 100 & \\
\hline Total & 24 & 66.7 & 12 & 33.3 & 36 & 100 & \\
\hline
\end{tabular}

Table 9. Correlatin of Work Stress with Menstrual Disorders on Tobacco Farmers at Ambulu Village, Jember City in 2018

\begin{tabular}{|c|c|c|c|c|c|c|c|}
\hline \multirow{3}{*}{ Work Stress } & \multicolumn{4}{|c|}{ Menstrual Disorder } & \multirow{2}{*}{\multicolumn{2}{|c|}{ Total }} & \multirow{3}{*}{ p-valuc } \\
\hline & \multicolumn{2}{|c|}{ Yes } & \multicolumn{2}{|c|}{ No } & & & \\
\hline & $\mathbf{n}$ & $\%$ & $\mathbf{n}$ & $\%$ & $\mathbf{N}$ & $\%$ & \\
\hline Low & 4 & 36.4 & 7 & 63.6 & 11 & 100 & \\
\hline Moderate & 16 & 76.2 & 5 & 23.8 & 21 & 100 & 0.025 \\
\hline High & 4 & 100 & 0 & 0 & 4 & 100 & \\
\hline Total & 24 & 66.7 & 12 & 33.3 & 36 & 100 & \\
\hline
\end{tabular}

with p-value of 0.715 . When it is compared to $\alpha$ of 0.05 , the p-value of 0.715 is greater than $\alpha$ so that it can be seen that there is no relationship between the period of work with menstrual disorders in tobacco farmers in Ambulu Village, Jember City.

\section{Correlation of Work Stress with Menstrual Disorders}

Most of the respondents included in the moderate stress category and experienced menstrual disorders as many as 16 people $(76.2 \%)$. Based on the results of statistical tests obtained the value of Pearson Chi Square with a p-value of 0.025 . When it is compared to $\alpha$ of 0.05 , the p-value of 0.025 is smaller than $\alpha$ so that it can be seen that there is a relationship between work stress and menstrual disorders in tobacco farmers in Ambulu Village, Jember City.

\section{DISCUSSION}

\section{Correlation of Age with Menstrual Disorders}

The results of the study on 36 respondents of female tobacco farmers in Ambulu Village, Jember City, found that the majority of respondents were between 35 and 44 years old, which is 20 people $(55.6 \%)$. From the results of statistical tests, it was found that there was no relationship between age and menstrual disorders in female farmers in Ambulu Village, Jember.

Fritz and Speroff (2011) stated that the more age increases, the more menstrual disorders suffered, especially the menstrual cycle disorders (menstrual cycle becomes shorter in proportion to age). The more increase the age of female workers, the more increase the FSH level which causes the follicular phase to be shorter but the LH level and duration of the luteal phase do not change. In this case, the menstrual cycle will remain regular, but the length and variability of the menstrual cycle will decrease. The length of the menstrual cycle reaches its lowest level around the age of 42 years.

This is not in accordance with Fahmi, Agushybana and Winarni (2018), which shows that there is a correlation between age and menstrual disorders in commuter workers in Demak City. Nohara et al. (2011) also showed a significant relationship between age and menstrual disorders. The majority of respondents in the study were not too old ( $>44$ years) so that they were still productive and the menstrual cycle was still regular and normal.

\section{Correlation between Marriage Status and Menstrual Disorders}

The results of the study on 36 respondents of tobacco farmers in Ambulu Village, Jember City 
were mostly married which is 33 people $(91.7 \%)$. Based on the results of statistical tests, it is known that there is no relationship between marital status and menstrual disorders.

This is not in accordance with the Karout, Hawai and Altuwaijri (2012) which showed that there is a relationship between marital status and menstrual disorders. Harsetianingrum (2015) also showed results there was no relationship between marital status and menstrual disorders. This is also not in accordance with the theory of Das and Ray (2010), which revealed that one factor in the occurrence of menstrual disorders in women is marital status. This is because married women tends to engage in active sexual activity, so that levels of estrogen can increase. High estrogen levels will cause menstrual disorders. One of them is a disruption in the menstrual cycle.

Based on the results of the study it can be seen that the majority of respondents have married status and experience menstrual disorders. However, there was no relationship between marital status and menstrual disorders based on the results of cross tabulation. This is probably due to other factors that have a tendency to cause menstrual disorders in tobacco farmers in Ambulu Village, Jember City.

\section{Correlation of Work Period with Menstrual Disorders}

The results of the study on 36 respondents of female tobacco farmers in Ambulu Village, Ambulu SubCity, Jember, found that most respondents had a working period of $>5$ years. From the results of statistical tests, it was found that there was no relationship between years of service and menstrual disorders in tobacco farmers in Ambulu Village, Jember City.

This is not in line with the research conducted Hassani et al. (2014). It is known that there is a relationship between individual characteristics such as age, length of work, BMI, and other factors such as work shifts, exercise, and work stress with menstrual disorders in female workers.

This is also not in accordance with the theory stated by Wiknjosastro (2009) who revealed that women who have a minimum working period, or just starting work are usually associated with menstrual disorders such as amenorrhea and disorders of the menstrual cycle. Health and Safety Executive (2006) explained that work done over a long period of time can cause health problems, one of which is reproduction effects such as menstrual disorders, prematurity, and increased abortion.

Harsetianingrum (2015) on female workers in One Shoe Factory in Sidoarjo showed that there was no relationship between years of work and menstrual disorders in women. In line with the research of Mamnu'ah et al. (2018), it is also known that there is no relationship between the period of work and menstrual disorders in the form of cycle disorders in female workers in one cigarette factory in the city of Lamongan.

\section{Correlation of Work Stress with Menstrual Disorders}

From the research conducted on 36 respondents of tobacco farmers in Ambulu Village, Jember City, it were that 16 respondents $(76.2 \%)$ are experiencing menstrual disorders. Based on the results of statistical tests, it is known that there is a relationship between work stress and menstrual disorders.

Previous research was conducted by Mulastin (2011) on female workers in Palemkerep Village, Jepara. It was found that there was a significant relationship between work stress and menstrual disorders $(\alpha=0.05, \rho=0.00)$. Zhou et al. (2010) in his research on female workers in China also concluded that there was a relationship between work stress and menstruation $(\alpha=0.05, \rho=0.01)$.

There are many impacts occuring when farmers do the work process on tobacco farming. This work always interacts with work and the environment that contains many hazards, such as potential physical, chemical, biological, and psychological hazards (Ernawati and Tualeka, 2013). One potential psychological hazard that can occur is work stress. Job stress experienced by respondents can be caused by excessive stressors, such as the demands of excessive work, the dual role of tobacco farmers as well as housewives, so that this can be a burden for female farmers.

Dhania (2010) stated that a bad work environment factor, one of which is excessive workload because of the high demands of work can cause stress to workers. In tobacco farmers in Ambulu Village, work stress experienced can be seen from several point of view, such as stress because of the state of the work environment and work processes, stress due to workload, work demands, and stress due to responsibility factors, and uncertain work time.

The mechanism of the relationship between work stress and menstruation is that work stress 
experienced by female workers will be responded to by the brain center (cortex). Information is reduced to the limbic (emotional brain). The hypothalamus then releases Corticotrophin Releasing Hormone $(\mathrm{CRH})$ and glucocorticoids. Gonadotropin and estrogen metabolism is depressed and makes menstruation abnormal (Zhou et al., 2010)

Mahdang et al. (2019) also stated that various factors in the work environment can cause work stress. The work stress on female workers can cause menstrual disorders and pregnancy disorders. Menstrual disorders that occur can be an indication and risk factor for some serious diseases, such as infertility, cancer, miscarriage and others. Improvement of the environment, coping with work stress, healthy lifestyles, and adequate nutritional intake are needed by workers (Rizal, 2016).

\section{CONCLUSION}

Tobacco farmers in Ambulu Village, Ambulu SubCity, Jember mostly experienced menstrual disorders are 24 people (66.6\%). Most respondents aged 35-44 years old, married, have a working period over 5 years, included in the category of moderate work stress. The conclusion of the study, there was a relationship between work stress with menstrual disorders, and there was no relationship between age, marital status, working period with menstrual disorders in tobacco farmers in Ambulu Village, Jember City.

\section{ACKWOLEDGEMENT}

We would like to show our gratitude to Anita Dewi Prahastuti S.KM, M.Sc., for her expert advice and encouragement throughout during this research, we also would like to thank the reviewers for theis insightful review on the paper, as these comments led us to improve this work. This research is far from perfect, but it is expected that it will be useful not only for the researcher but also for the readers. For this reason, constructive thoughtfull suggestion and critics are welcomed.

\section{REFERENCES}

Biro Riset BUMN (2015) Profile of the Agriculture Industry in Indonesia, Jakarta: Statistics IndonesiaStatistic Indonesia.

Das, D. and Ray, S. (2010) 'Variation in Menstrual Characters: A study between Married and
Unmarried Women of West Bengal', Collegium Antropologicum, 34(3), pp. 989-994.

Dhania, D. R. (2010) 'Pengaruh Stres Kerja, Beban Kerja terhadap Kepuasan ( Studi pada Medical Representatif di Kota Kudus )', Jurnal psikologi Universitas Muria Kudus, I(1), pp. 15-23.

Direktur Statistik Kependudukan dan Ketenagakerjaan (2017) Survei Angkatan Kerja Nasional 2017, Jakarta: Statistics Indonesia.

Ernawati, D. and Tualeka, A. R. (2013) 'Risk Assesment dan Pengendalian Risiko pada Sektor Pertanian (Studi Kasus di Pertanian Bawang Merah Desa Kendalrejo, Kecamatan Bagor, Kabupaten Nganjuk)', The Indonesian Journal of Occupational Safety and Health, 2(2), pp. $154-161$.

Fahmi, U. L., Agushybana, F. and Winarni, S. (2018) 'Faktor-Faktor yang Berhubungan dengan Gangguan Menstruasi pada Commuter (Penglaju) (Studi Kasus di Kecamatan Karangawen Kabupaten Demak Tahun 2018)', Jurnal Kesehatan Masyarakat (e-Journal), 6(5), pp. 230-240.

Fritz, M. A. and Speroff, L. (2011) Clinical Gynecologic Endocrinology and Infertility. 8th edn. Philadelphia: Lippincott Williams \& Wilkins.

Harlow, S. D., Windham, G. and Paramsothy, P. (2013) 'Menstruation and Mentrual Disorders', in Goldman, M. B., Troisi, R., and Rexrode, K. M. (eds) Women and Health. 2nd edn. Calofirnia: Academic Press.

Harsetianingrum, R. A. (2015) Analisis Risiko terjadinya Gangguan Menstruasi pada Tenaga Kerja Wanita di PT. XYZ, Sidoarjo. Undergraduate Thesis. Surabaya: Faculty of Public Health, Universitas Airlangga.

Hassani, S. et al. (2014) 'Menstrual Disturbances and Hormonal Changes in Women Workers Exposed to a Mixture of Organic Solvents in a Pharmaceutical Company', Medical Journal of the Islamic Republic of Iran (MJIRI), 28(156), pp. 1-10.

Health and Safety Executive (2006) Managing Shiftwork, Health and Safety Guidance. Kew: Health, Safety and Executive.

Herman, M. C. et al. (2017) 'Is the Pictorial Blood Loss Assessment Chart (PBAC) Score Associated with Treatment Outcome after Endometrial Ablation for Heavy Menstrual Bleeding? A Cohort Study', BJOG: An International Journal of Obstetrics and Gynaecology, 124(2), pp. 277-282. 
Herminingsih, H. and Rokhani (2014) 'Pengaruh perubahan iklim terhadap perilaku petani tembakau di kabupaten jember', Jurnal Matematika, Saint, dan Teknologi, 5(1), pp. 42-51.

Indonesian Center for Estate Crops Research and Development (2017) Cultivation of Tobacco, Bogor: Indonesian Center for Estate Crops Research and Development.

Karout, N., Hawai, S. M. and Altuwaijri, S. (2012) 'Prevalence and Pattern of Menstrual Disorders among Lebanese Nursing Students', Eastern MediterraneanHealth Journal, 18(4), pp. 346352.

Lindbohm, M.-L., Taskinen, H. and Sallmén, M. (2013) 'Reproductive Hazard of Occupational and Environmental Exposures', in Goldman, M. B., Troisi, R., and Rexrode, K. M. (eds) Women and Health. 2nd edn. Calofirnia: Academic Press.

Mahdang, P. A. et al. (2019) 'An Analysis about the Influence between Occupational Factors and Work Environment on Abortus Occurrence in Female Workers at PT.X Sidoarjo', Indian Journal of Public Health Research \& Development, 10(5), pp. 1479-1485.

Mamnu'ah, I. et al. (2018) 'Hubungan Masa Kerja, Tingkat Kecemasan, Penggunaan Masker dan Paparan Bahan Rokok terhadap Gangguan Siklus Menstruasi Karyawan Wanita Pabrik Rokok di Lamongan', Jurnal Kesehatan Masyarakat (e-Journal), 6(1), pp. 129-137.

Ministry of Health Data and Information Center (2015) 'Situasi Kesehatan Reproduksi Remaja'. Jakarta: Ministry of Health Republic of Indonesia.
Mulastin (2011) 'Hubungan Stres dengan Siklus Menstruasi pada Wanita Pekerja di Desa Pelemkerep Kecamatan Mayong Kabupaten Jepara', Jurnal Kebidanan Akbid Alhikmah, 1(1), pp. 1-12.

Nohara, M. et al. (2011) 'Menstrual Cycle and Menstrual Pain Problems and Related Risk Factors among Japanese Female Workers', Industrial Health, 49(2), pp. 228-234.

Notoatmodjo, S. (2012) Metodologi Penelitian Kesehatan. Jakarta: Rinneka Cipta.

Prawirohardjo, S. (2011) Ilmu Kandungan. Jakarta: PT. Bina Pustaka.

Rizal, M. (2016) 'Hubungan Stres Kerja dengan Menstruasi Abnormal Pekerja Konveksi Desa Pegandon Pekalongan', Unnes Journal of Public Health, 5(3), pp. 205-214.

Sudibyo, M. (2015) Petani Tembakau di Indonesia : Sebuah Paradoks Kehidupan. Jakarta: Lembaga Pengembangan Sosial Indonesia.

Suma'mur (2009) Higiene Perusahaan dan Kesehatan Kerja. Jakarta: Gunung Agung.

Tarar, M. A. et al. (2016) 'Health Problems Faced by Female Farm Workers in Rural Areas of Tehsil Dera Ghazi Khan: A Sociological Investigation', Journal of the Dow University of Health Sciences, 10(1), pp. 35-38.

Wiknjosastro (2009) Obstetrics and Gynecology. Jakarta: PT Bina Pustaka.

Zhou, M. et al. (2010) 'Work and Family Stress is Associated with Menstrual Disorders but not with Fibrocystic Changes: Cross-Sectional Findings in Chinese Working Women', Journal of Occupational Health, 52(6), pp. 361-366. 